\title{
Implementation of Cloud Platform to Improve Project Performance
}

\author{
Li-Ren Yang/Tamkang University \\ Department of Business Administration \\ New Taipei City, Taiwan \\ iry@mail.tku.edu.tw
}

\begin{abstract}
Conceptualizing implementation of cloud platform in the project management (PM) context is still rudimentary. Previous studies have not empirically examined the role of cloud-based information management platform in PM, and their effect on project performance. Thus, developing such support will illustrate the benefits of cloud platform implementation. The primary objective of this study is to evaluate how customer relationship management (CRM) can enable innovation capabilities and then improve the project performance by implementing cloud platform. This study empirically investigated a sample of projects in the Taiwanese industry. The structural equation modeling (SEM) approach was used to validate the research model. The findings indicate that implementation of cloud platform is associated with customer relationship management. In addition, these analyses suggest that customer relationship management has a positive effect on innovation capabilities and then on project and market performance.
\end{abstract}

Keywords-cloud platform; customer relationship management; innovation capability; project management

\section{INTRODUCTION}

Information technology (IT) plays an important role in supporting the strategic goals of a company. It is important for firms to innovate their products in a timely manner. Globalization pressure has caused many firms to employ IT to respond quickly to environmental changes and customer demand and to reach enterprise goals. One source of value of IT to the firm is through the creation of new business processes, including the innovation process. IT can enhance the base of knowledge available to a new product development team and improve coordination, communication, and cooperation among team members [1].

Prior research examined the effects of IT adoption, but the research findings were contradictory. In addition, no previous studies have empirically analyzed the effects of cloud platform implementation on new product development (NPD) performance. Due to this deficiency, this study attempted to evaluate the association between implementation of cloud platform and NPD performance. However, measuring IT's contributions in isolation without considering contextual variables cannot produce a meaningful indication of IT's business value [2]. Accordingly, it is necessary to explore the intermediate variables to make underlying mechanisms through which IT adoption influences performance clearly [3]. Previous studies suggested that IT adoption has a positive effect on innovation capability, which is an important factor influencing NPD performance [4]. Prior research also illustrated the importance of CRM because it plays a critical role between IT adoption and innovation capability [5]. Thus, the primary purpose of this study is to examine the effects of implementation of cloud platform on two variables, customer relationship management and innovation capabilities, and then on NPD performance.

\section{CONCEPTUAL FRAMEWORK AND RESEARCH HYPOTHESES}

New product development is a risky and complicated process in terms of time consumption, large investment, and complex coordination among crossfunctional members [6]. IT applications play an important role in NPD efforts because such tools can provide effective media for communicating and disseminating information [7]. While NPD team members and customers accomplish their tasks simultaneously, IT can facilitate their communication, interaction, and collaboration. In addition, because the NPD team members and customers are from different units and have different perspectives on products, IT can be used as a flexible communication and coordination platform. Customer relationship management is a cross functional, customer driven, technology integrated into business process and a management strategy that maximizes relationships which encompasses the entire organization [8]. Service delivery via the advent of new products and options for various channels of delivery through IT applications has emerged as an important attribute in satisfying customers and managing customer relationship [9]. IT practices can help enhance customer relationship management by increasing convenience, collecting service performance information for management use, and offering extra services [10]. In addition, Oghojafor et al. [11] confirmed the relationship between information technology adoption and customer relationship management. This study extends previous research by addressing the effects of implementation of cloud platform on customer relationship management. Based on the relevant literature, this study develops the following research hypothesis: 
H1: Implementation of cloud-based information management platform positively influences customer relationship management.

Previous studies identified customer involvement as an important factor for manufacturers to launch successful new products [12]. Customer participation in NPD process can enhance innovation capability to develop more differentiated products for particular target markets [13]. Previous studies stated that customer involvement in the early stages of NPD activities, manufacturing technical meetings, and market evaluation conferences can also encourage customers to assist with the processes of NPD, and improvement of manufacturing techniques and product designs to benefit the innovation process [5]. Moreover, companies which promote customer relationship management can understand and predict future market changes through customer participation, which is beneficial for them to cooperate with customers to implement innovative management methods [14]. Accordingly, CRM activities contribute significantly to innovation capabilities. Based on the relevant literature, the following hypothesis is postulated and tested:

H2: Customer relationship management has a positive effect on innovation capabilities.

Previous studies have long considered innovativeness as an important firm capability that drives organizational change and renewal [15]. IT is viewed as useful to product innovation of cross-functional team since it can coordinate the activities of different functions effectively, and make communication and information exchange among functions more convenient [16]. Organizations can enhance the innovation capability by using information technology [17]. Firms that fail to efficiently and effectively translate their IT capabilities into commercial success of innovation cannot expect to realize the potential of competitive advantage from these capabilities [18]. Thus, adopting IT can be beneficial to a firm and leads to enhanced innovation capability. This study extends previous research by addressing the effects of implementation of cloud platform on innovation capabilities in NPD. Based on these arguments, the following hypothesis is proposed:

H3: Implementation of cloud-based information management platform positively influences innovation capabilities.

While an innovation strategy is key to long-term success, firms should always invest heavily in R\&D and speed new products to market [4]. The literature suggested that innovation capability provides benefits for the firm and helps improve performance outcomes [19]. Firms can use innovation capability to develop the products and markets and then to overtake it with their improved products [20]. Accordingly, innovation capability has a substantial effect on new product success. This leads to the following hypothesis:

H4: Innovation capabilities positively influence project and market performance.

\section{METHODOLOGY}

\section{A. Research Instrument}

The survey instrument was developed to measure implementation of cloud-based information management platform and new product development performance in the Taiwanese industry. Study participants were first asked to identify a recent project that they were familiar with for assessment. The survey was composed of five sections: 1) cloud platform implementation, 2) customer relationship management, 3) innovation capabilities, 4) project and market performance, and 5) project and personal information.

\section{B. Sampling Method}

Individuals interested in participating in the study were identified by a search from various industry associations. A survey of NPD projects was conducted in the Taiwanese industry. The data collection tool was developed to collect project-based data. The targeted respondents were identified as the senior individuals who were familiar with implementation of cloud platform, customer relationship management, innovation capabilities, and project performance. In order to obtain a truly representative sample, the geographic mix of projects was intentionally diverse. Additionally, a specified mix of project type was targeted in order to obtain a representative sample of the industry.

All of the companies were contacted via phone or email to identify the person involved in projects by name and title. The investigators then contacted the respondents to confirm their participation in this study. This approach helped the investigators select the right respondents who possess adequate knowledge to properly evaluate the subjective project and are capable of answering all of the survey questions. Project responses were collected via paper and online surveys. The projects were examined to ensure that no duplicate project information was collected.

\section{Survey Design and Construct Measurement}

Multi-item scales were developed for each of the variables included in the theoretical model. The items used to measure implementation of cloud platform were based on Cooper and Kleinschmidt [21]. This study evaluates implementation of cloud platform in six important areas: product idea, preliminary assessment, conceptual design, product development, product test, and mass production. On the other hand, the scales developed by Lin et al. [5] were adapted to evaluate customer relationship management and innovation capabilities. This study focuses on the three most important types of CRM activities in NPD: joint problem solving, long-term partnership, and customer involvement. In addition, this study examines the four most important innovation capabilities in NPD: product innovation, process innovation, administrative innovation, and marketing innovation. Questions from Atuahene-Gima [22] were adapted to measure new product development performance, including market performance and project performance. The survey used these items because the literature and recommendations of five NPD practitioners have shown that these items are closely linked to new product development 
projects. Each item was rated on a 7-point scale, where 1 represented strongly disagree and 7 represented strongly agree.

\section{RESULTS AND ANALYSIS}

\section{A. Measurement Model Test Results}

Prior to estimating the structural model, a confirmatory factor analysis (CFA) was conducted to verify the measurement model. Multiple fit criteria were used to assess the overall fit of the model. In the proposed model, implementation of cluster platform, customer relationship management, innovation capabilities, and NPD performance are a second order construct. The data were analyzed using the AMOS/SPSS statistical package. The model refinement was performed to improve the fit to its recommended levels. Based on several trials resulting in elimination of some of the items, all of the scales met the recommended levels. Furthermore, the composite reliability for all constructs was above the 0.7 level, indicating adequate reliability for each construct. Thus, the results provide evidence that the scales are reliable.

All of the factor loadings are statistically significant at the five percent level and exceed the 0.5 standard. In addition, all constructs have an average variance extracted (AVE) greater than 0.5 . Thus, these constructs demonstrate adequate convergent validity. Discriminant validity evaluates whether the constructs are measuring different concepts. The procedure requires comparing the set of models where each pair of latent constructs has a constrained correlation of one with the correspondent models where such pairs of constructs are freely estimated. The results show that the chisquare values are significantly lower for the unconstrained models at the five percent level, which suggests that the constructs exhibit discriminant validity.

\section{B. Structural Model Test Results}

Figure 1 presents results of the overall model fit in the structural model. A feasible model was selected based on the recommended Goodness-Of-Fit (GOF) measures and the model that satisfies both theoretical expectations and GOF was finally selected for structural equation modeling (SEM) analysis. Thus, the model refinement was performed to improve the fit to its recommended levels. Based on several trials resulting in elimination of some of the items (including the items associated with mass production and product innovation variables), this model yielded a model fit of $\chi^{2}=122.33, \mathrm{p}=0.00, \mathrm{NFI}=0.927, \mathrm{CFI}=0.940, \mathrm{GFI}=$ 0.922 , AGFI $=0.848$, and RMSEA $=0.074$. The overall fit statistics indicated a very good fit for the model. Thus, the result supported the hypothesized relationship.

The test of H1, H2, H3, and $\mathrm{H} 4$ was based on the direct effects (structural coefficients) among the constructs as shown in Figure 1. H1 proposed a positive relationship between implementation of cloud platform and customer relationship management. This hypothesis was supported since the standardized coefficient was 0.79 and statistically significant $(\mathrm{p}<0.001)$. H2 proposed a positive relationship between customer relationship management and innovation capabilities. This hypothesis was supported by a statistically significant structural coefficient of 0.55 ( $\mathrm{p}<0.001)$. H3 proposed a positive relationship between implementation of cloud platform and innovation capabilities. This hypothesis was also supported with a standardized coefficient of 0.30 (p $<0.01)$. In addition, the direct impact from innovation capabilities to NPD performance is significant $($ coefficient $=$ $0.87 ; \mathrm{p}<0.001$ ), and therefore $\mathrm{H} 4$ is supported.

\section{CONCLUSIONS AND DISCUSSION}

\section{A. Major Findings}

The research findings indicate that adoption of cloud platform is associated with customer relationship management, which supports $\mathrm{H} 1$. These results are in line with previous studies, which have shown that information technology plays a crucial role in CRM. Additionally, in agreement with previous studies, the research findings imply that customer relationship management can improve innovation capabilities in NPD, which supports H2. The research results also show that implementation of cloud platform may enhance innovation capabilities in NPD, which supports H3. The positive relationship is in line with previous findings. In addition, the direct impact from innovation capabilities to NPD performance is significant. Thus, the positive relationship suggests that $\mathrm{H} 4$ is supported.

\section{B. Limitations and Suggestions for Future Research}

While this study offers important insights into implementation of cloud platform, there are some limitations. First, results are obtained from only one industry (i.e., hightech industry). Thus, generalizations should be drawn with care. It would be helpful to conduct similar studies in traditional manufacturing industry. Additionally, it would be interesting to reexamine the moderating relationship between innovation capabilities and NPD performance for environmental factors such as salary, job satisfaction, working hours, information availability, time availability, team relationship, and project duration. Finally, this study focuses on external customer relationship management. The effect of internal CRM mechanisms, such as organization and knowledge management [5], need to be examined in the future.

\section{REFERENCES}

[1] Dewitt, T. and Jones, G. (2001), "The role of information technology in the organization: a review, model and assessment", Journal of Management, Vol. 27 No. 3, pp. 313-46.

[2] Lee, C.S. (2001), "Modeling the business value of information technology", Information and Management, Vol. 39, 191-210.

[3] Barua, A., Lee, C.H.S. and Whinston, A.B. (1996), "The calculus of reengineering", Information Systems Research, Vol. 7 No. 4, pp. 40928.

[4] Zhou, K.Z. (2006), "Innovation, imitation, and new product performance: the case of China", Industrial Marketing Management, Vol. 35 No. 3, pp. 394-402.

[5] Lin, R., Chen, R. and Chiu, K.K. (2010), "Customer relationship management and innovation capability: an empirical study", Industrial Management \& Data Systems, Vol. 110 No. 1, pp. 111-33. 
[6] Sarin, S. and McDermott, C. (2003), "The effect of team leader characteristics on learning, knowledge application, and performance of cross-functional new product development teams", Decision Sciences, Vol. 34 No. 4, pp. 707-39.

[7] Keary, M.Y. (2012), "Knowledge development and social change through technology: emerging studies", Online Information Review, Vol. 36 No. 4, pp.621-2.

[8] Goldenberg, B. (2000), "What is CRM? What is an e-customer? Why you need them now?", paper presented at DCI Customer Relationship Management Conference, Boston, MA.

[9] Heskett, J.T., Sasser, W.E. and Schlesinger, L.A. (1997), The Service Profit Chain, The Free Press, New York, NY.

[10] Furey, T.R. (1991), "How information power can improve service quality”, Planning Review, Vol. 19 No. 3, pp. 24-6.

[11] Oghojafor, B.E.A., Aduloju, S.A. and Olowokudejo, F.F. (2011), "Information technology and customer relationship management (CRM) in some selected insurance firms in Nigeria", Journal of Economics and International Finance, Vol. 3 No. 7, pp. 452-61.

[12] Dow, D., Samson, D. and Ford, S. (1999), "Exploding the myth: do all quality management practices contribute to superior quality performance?", Production and Operations Management, Vol. 8 No. 1, pp. 1-27.

[13] Lagrosen, S. (2005), "Customer involvement in new product development: a relationship marketing perspective", European Journal of Innovation Management, Vol. 8 No. 4, pp. 424-36.

[14] Slater, S.F. and Narver, J.C. (1995), "Market orientation and the learning organization", Journal of Marketing, Vol. 59 No. 3, pp. 6374.
[15] Linder, J.C., Jarvenpaa, S. and Davenport, T.H. (2003), "Toward an innovation sourcing strategy", MIT Sloan Management Review, Vol. 44 No. 4, pp. 43-9.

[16] Chen, C. (2007), "Information technology, organizational structure, and new product development - the mediating effect of crossfunctional team interaction", IEEE Transactions on Engineering Management, Vol. 54 No. 4, pp. 687-98.

[17] Tarafdar, M. and Gordon, S. (2007), "Understanding the influence of information systems competencies on process innovation: a resourcebased view", Journal of Strategic Information Systems, Vol. 16 No. 4, pp. 353-92.

[18] Huang, M., Ahn, J. and Lee, D. (2009), "IT capabilities and firm performance: the moderating role of institutional pressures and the mediating role of IT innovation success", paper presented at the Fifteenth Americas Conference on Information Systems, San Francisco, CA.

[19] Kmieciak, R., Michna, A. and Meczynska, A. (2012), "Innovativeness, empowerment and IT capability: evidence from SMEs", Industrial Management \& Data Systems, Vol. 112 No. 5, pp. 707-28.

[20] Shankar, V., Carpenter, G.S. and Krishnamurthi, L. (1998), "Late mover advantage: how innovative late entrants outsell pioneers", Journal of Marketing Research, Vol. 35 No. 1, pp. 54-70.

[21] Cooper, R.G. and Kleinschmidt, E.J. (1993), "Uncover the keys to new product success", Engineering Management Review, Vol. 11 No. 4, pp. 5-18.

[22] Atuahene-Gima, K. (1995), "An exploratory analysis of the impact of market orientation on new product performance - a contingency approach”, Journal of Product Innovation Management, Vol. 12 No. 4, pp. 275-93.

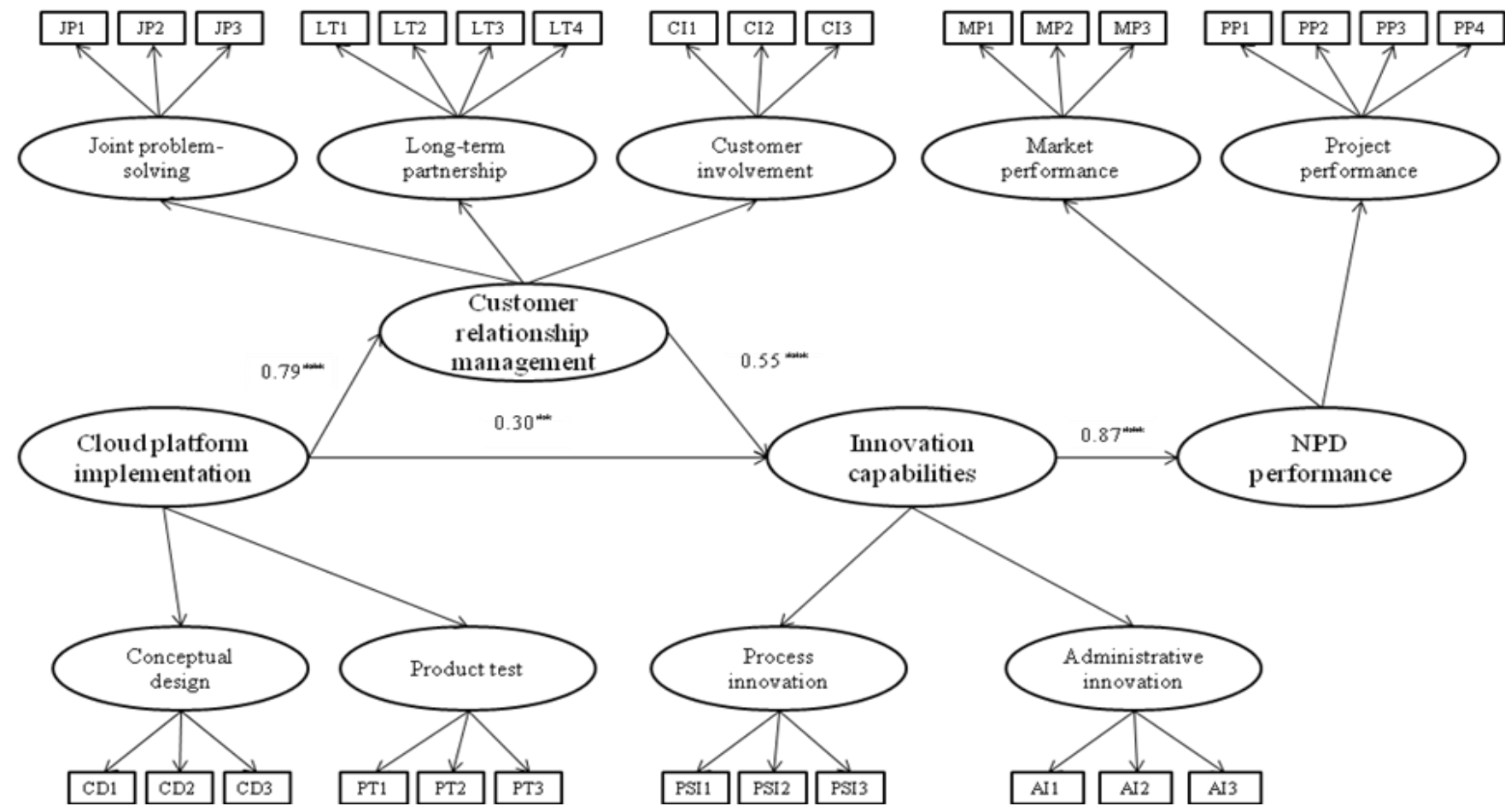

Figure 1. Research model estimation results 